\title{
Influence of fire barriers on fire performance of facades with combustible insulation
}

\author{
Dubravka Bjegovic $^{1}$, Ivana Banjad Pecur ${ }^{1}$, Birgitte Messerschmidt ${ }^{2}$, Bojan Milovanovic ${ }^{1}$ \\ and Marina Alagusic ${ }^{1}$ \\ ${ }^{1}$ University of Zagreb, Faculty of Civil Engineering, Croatia \\ ${ }^{2}$ Fire Safe Europe, Belgium
}

\begin{abstract}
In today's modern society sustainability has become a key driver for innovation. Sustainability in buildings is, or at least it should be, strongly interconnected with energy efficiency and fire safety. Unfortunately, cases of fires in buildings all over the world are a wakeup call to start thinking of fire safety as an inevitable part of energy efficiency in buildings. Thermally enhanced building envelopes, due to materials used, can represent significantly increased fire load on façades. To determine their fire performance, it is necessary to move on from material level to the whole building level, i.e. full scale tests. This paper presents findings from comprehensive research on influence of fire barrier on fire performance of External Thermal Insulation Composite System - ETICS with combustible thermal insulation. To confirm findings, tests on identical ETICS systems were conducted in March 2014 and May 2014.
\end{abstract}

\section{INTRODUCTION}

Having sustainable and energy efficient buildings are exciting new trends which are driving the innovation of new construction products and systems. Unfortunately what is often forgotten is that if a building is to be truly sustainable it should not be built to burn. Examples of fires in different building types all over the world are proof of an urgent need to start considering fire safety as an integral part of sustainable building design. Sustainable buildings cannot be achieved without a holistic approach, which implies that sustainable buildings are at the same time energy efficient and fire safe. It can be said that buildings are sustainable only when they perform better in terms of energy consumption, are resilient and provide safety for various users and use types of the building, while at the same time they minimize the need to replace material resources over the building's lifetime.

Considering that in Europe buildings use $41 \%$ of all energy, and 2/3 of this energy consumption is due to heating and cooling, buildings are an obvious and necessary target for energy saving measures. One of the obvious ways of reducing energy consumption in buildings is to add thermal insulation to the envelope of the building. Often this leads to the use of highly insulating façade systems. To secure the fire safety of buildings it is therefore necessary to be able to test how highly insulated façade systems perform in fire. Due to the complex nature of these systems it is not sufficient to only consider the performance of individual materials on their own. The interaction of different materials within the

This is an Open Access article distributed under the terms of the Creative Commons Attribution License 2.0, which permits unrestricted use, distribution, and reproduction in any medium, provided the original work is properly cited. 
Table 1. Description of test specimens.

\begin{tabular}{|c|c|c|c|c|}
\hline $\begin{array}{c}\text { TEST } \\
\text { SPECIMEN }\end{array}$ & $\begin{array}{c}\text { Thermal insulation } \\
\text { material and thickness }\end{array}$ & Render & $\begin{array}{c}\text { Fixing } \\
\text { method }\end{array}$ & $\begin{array}{c}\text { Reaction to fire } \\
\text { classification }\end{array}$ \\
\cline { 1 - 2 } TS_1 & $\begin{array}{c}\text { Expanded polystyrene (EPS) }- \\
150 \mathrm{~mm}\end{array}$ & $\begin{array}{c}\text { Basic render reinforced with } \\
\text { glass fibre mesh and } \\
\text { final organic (acrylic) } \\
\text { render }-5 \mathrm{~mm}\end{array}$ & $\begin{array}{c}\text { Adhesive } \\
\text { and } \\
\text { anchoring }\end{array}$ & $\begin{array}{c}\text { B-s2,d0 } \\
\text { TS_2 } 2 \text { (A2-s1,d0 } \\
\text { barrier) }\end{array}$ \\
\hline
\end{tabular}

system on building level are key to how it will perform in fire and it is therefore necessary to test façade systems in a test that replicates a realistic fire scenario.

The main aim of this paper is twofold: first, to provide deeper understanding of the fire performance of External Thermal Insulation Composite Systems (ETICS) with combustible thermal insulation, which are nowadays one of the most commonly used technologies to thermally enhance building envelopes in Europe [1] and second, to investigate whether the fire barrier constructed above openings influence fire performance of ETICS system with combustible thermal insulation.

\section{EXPERIMENTAL PART}

\subsection{Experimental methodology and set-up}

In the absence of a harmonised EU standard for large scale façade fire testing, fire performance test of ETICS system in these experiments was performed according to BS 8414-1 test method [2]. This standard describes a method of assessing the behaviour of façade systems applied to the face of a building with a masonry wall and exposed to external fire under controlled conditions. The fire exposure is representative of an external fire source or a fully-developed (post flashover) fire in a room, venting through an opening such as a window aperture that exposes the cladding to the effects of external flames [2].

Test results presented and analysed in this paper, were obtained during research conducted in March 2014 and May 2014, i.e. Test 1 and Test 2, respectively. Both in Test 1 and Test 2, respectively, identical systems were constructed and tested (Table 1). By conducting measurements on identical full scale test specimens during two tests, the repeatability of testing ensured comparability of obtained results and therefore confirmation of fire performance of tested systems, i.e. influence of fire barrier on fire performance of ETICS system with combustible thermal insulation.

Both test specimens were L-shaped, $8 \mathrm{~m}$ high, with one leg $2.6 \mathrm{~m}$ long forming the main test wall (main face) and the other leg $1.5 \mathrm{~m}$ long forming the return wall (wing) as shown in Fig. 1. The L-shape of the specimen represents an internal corner of a building. The only difference between test specimens was the fire barrier made of non-combustible stone wool (SW) thermal insulation that was constructed above the opening of one test specimen. Composition of test specimens and their classification according to the reaction to fire classification as declared by the manufacturer [3, 4] is shown in Table 1 .

Fire barrier in the test specimen TS_2 was positioned directly above the combustion chamber which simulates an opening in a building, Fig. 2a. Lintel protection above each opening prevents fire penetration in the thermal insulation layer. A schematic drawing of the lintel protection above the opening on test specimen TS_2 is shown in Figure 2b. It was constructed with respect to the best rules of practice. According to literature [5], this is one of the possible ways of constructive "fire protection", i.e. passive fire protection in ETICS systems with combustible thermal insulation.

The heat source placed in the combustion chamber was in accordance with BS 8414-1. This heat source releases a nominal total heat output of $4500 \mathrm{MJ}$ over $30 \mathrm{~min}$ at a peak rate of $(3 \pm 0.5) \mathrm{MW}$. It needs to be pointed out that BS 8414-1 standard was used only as a "guide" for preparing and 


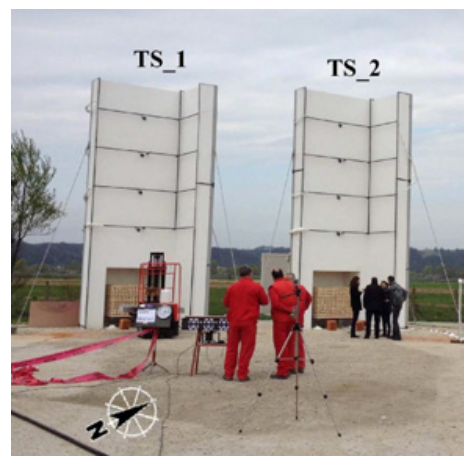

Figure 1. Test specimens before the test start.

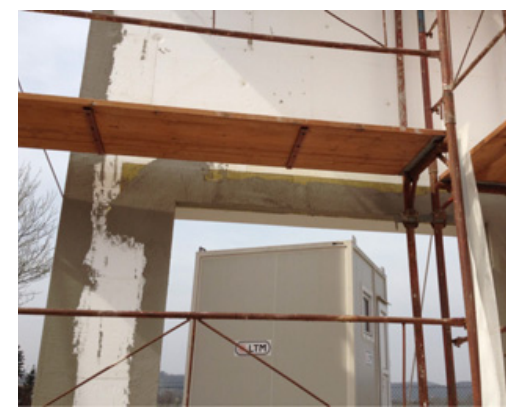

a)

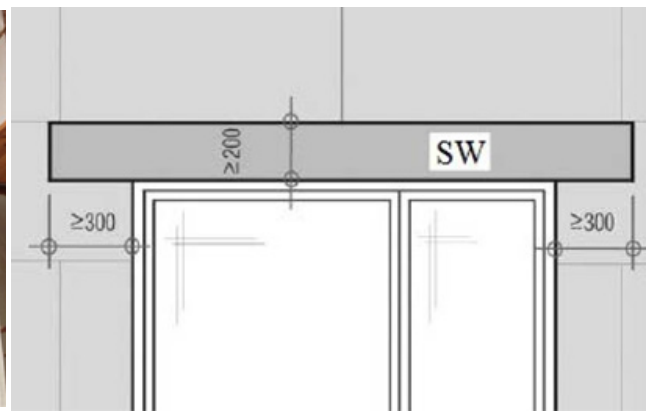

b)

Figure 2. Lintel protection: a) Applied on test specimen TS_ 2, b) General scheme [5].

Table 2. Description of additional measurements performed.

\begin{tabular}{|c|c|c|c|}
\hline Measuring instrument & Purpose & Number and position & *Note \\
\hline $\begin{array}{c}\text { Additional internal } \\
\text { thermocouples (In } \\
\text { TCadd) } 1.5 \mathrm{~mm}\end{array}$ & $\begin{array}{c}\text { Measuring temperature } \\
\text { distribution in thermal insulation } \\
\text { layer }\end{array}$ & $\begin{array}{c}10 \text { thermocouples per test } \\
\text { specimen }(7 \text { on main face and } \\
3 \text { on wing) }\end{array}$ & $\begin{array}{c}\text { Used only } \\
\text { in Test } 2\end{array}$ \\
\hline $\begin{array}{c}\text { Load cell under the } \\
\text { support platform legs } \\
\text { (LC) }\end{array}$ & $\begin{array}{c}\text { Measuring weight loss rate of } \\
\text { the wood crib during the test; i.e. } \\
\text { burning rate of fire source }\end{array}$ & $\begin{array}{c}\text { Placed below each leg of } \\
\text { platform onto which the wood } \\
\text { crib was placed. }\end{array}$ & $\begin{array}{c}\text { Used in } \\
\text { Test } 1 \text { and } \\
\text { Test } 2\end{array}$ \\
\hline
\end{tabular}

conducting this test, since the main aim was to gain new knowledge about complex fire performance of ETICS system with combustible thermal insulation on a building level and influence of fire barrier on its fire performance. The deviations from BS 8414-1 were that the tests were performed outside and in addition to the standard temperature measurements defined by BS 8414-1, additional measurements were conducted, as described further in this chapter.

External thermocouples were positioned on the main face of the façade and on the wing, both at Level 1 and Level 2 (Fig. 3a) in accordance with BS 8414-1. Internal thermocouples required by BS 8414-1 were positioned at Level 2, on the main face of the façade and on the wing.

Table 2 shows the additional measurements done during the tests with Fig. 3b showing the position of the additional internal thermocouples and load cells. The results of these are part of the analysis in this paper. 


\section{MATEC Web of Conferences}

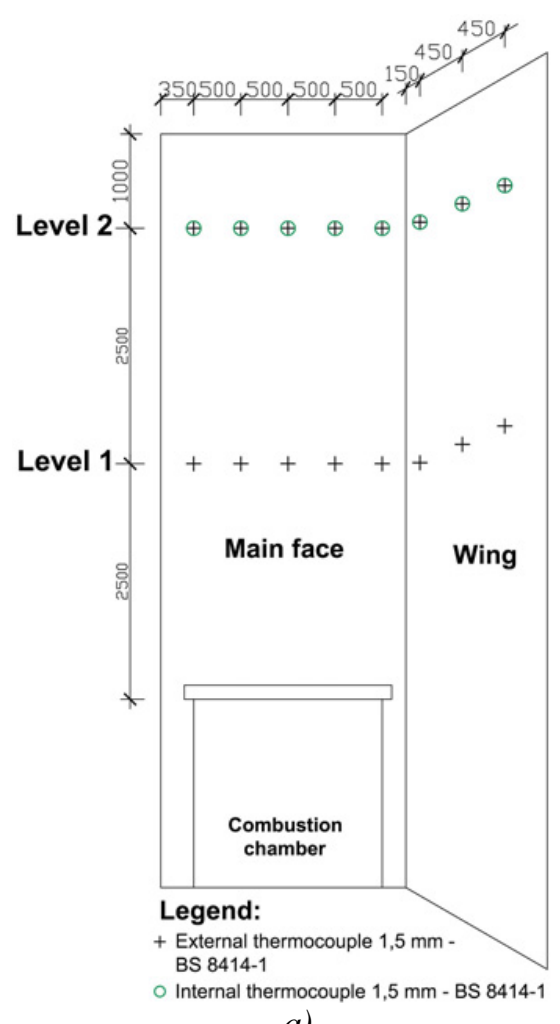

a)

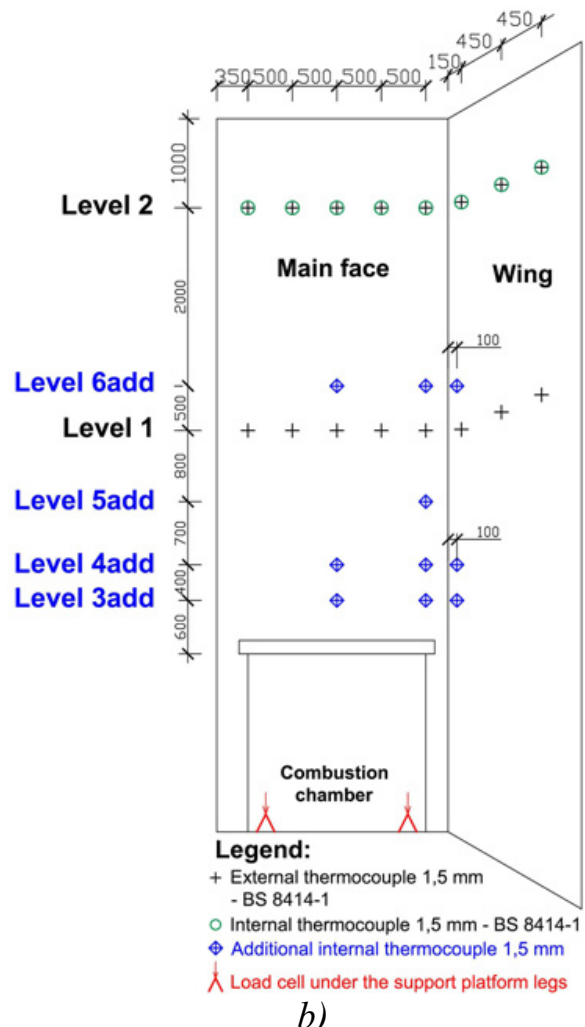

b)

Figure 3. Positioning scheme of: a) thermocouples required by BS 8414-1 [2]; b) load cells and additional internal thermocouples.

For both test specimens, i.e. TS_1 and TS_2, the wood crib has been ignited at the same time with the aim that the fire development and fire spread on both test specimens could be visually comparable.

Since the tests were performed outside, the weather conditions, i.e. wind speed, wind direction and air temperature, were monitored in order to be able to take into account their possible influence on testing and obtained results. During the Test 1 , the air temperature at the start of the test was within the range $11.2-12.3^{\circ} \mathrm{C}$. The air velocity was $1.8 \mathrm{~m} / \mathrm{s}$ at the start of the tests, while during the test air velocity was measured up to $5.4 \mathrm{~m} / \mathrm{s}$ in N-E direction. Air temperature during the Test 2 was within the range of $20.5-22.2^{\circ} \mathrm{C}$ and the air velocity was within the range of $2.2-4.5 \mathrm{~m} / \mathrm{s}$ in N, N-W direction. Direction of north is shown in Fig. 1.

\subsection{Test results}

Test results indicating fire performance of ETICS systems with combustible thermal insulation, with and without SW fire barrier, will be presented in terms of developed temperature profiles, mass loss of fire source, i.e. wood crib, and visual appearances on test specimens. Behaviour of tested ETICS systems in this type of fire scenario (fire occurs inside a building and spreads to the façade due to venting through an opening) will be compared, thus the influence of SW fire barrier on the fire performance of ETCIS system with combustible thermal insulation will be evaluated. Furthermore, test results obtained in Test 1 and Test 2 will be shown parallel, so the temperature evolution behaviour of test specimens could be easily noticed. 


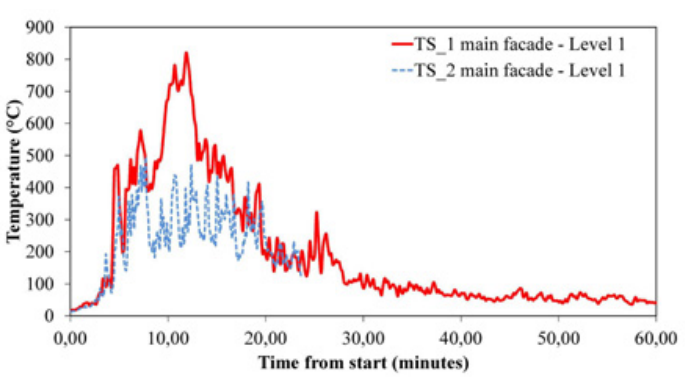

a)

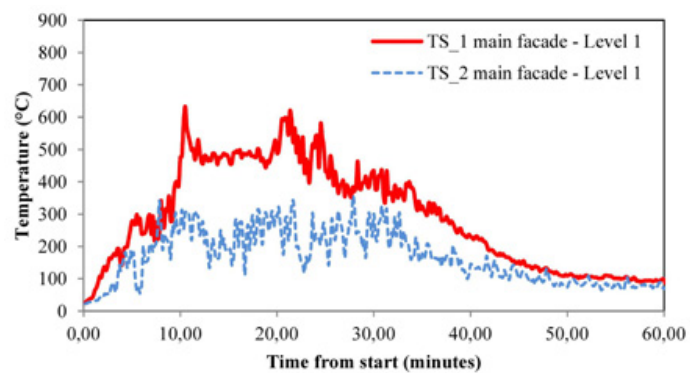

b)

Figure 4. Average surface temperature at Level 1 on main facade: a) Test 1, b) Test 2.

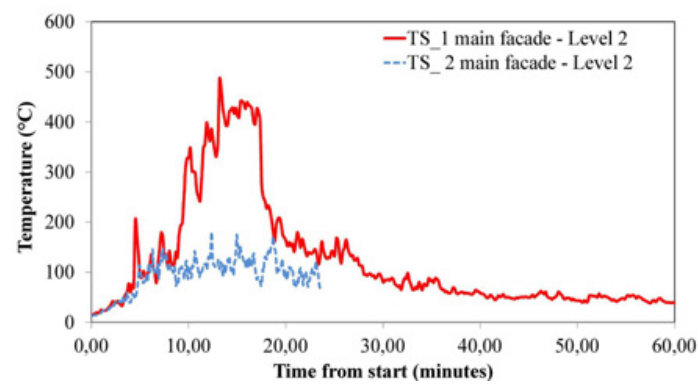

a)

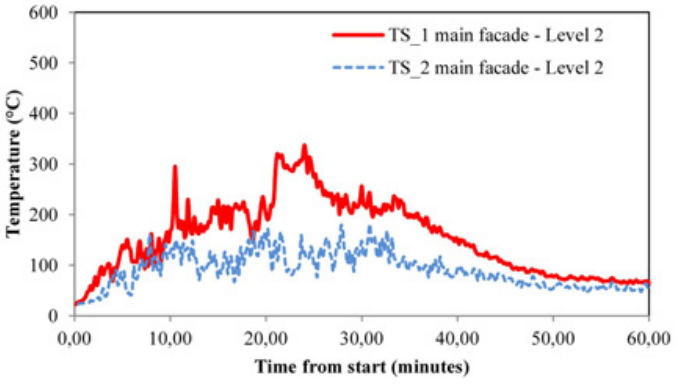

b)

Figure 5. Average surface temperature at Level 2 on main facade: a) Test 1, b) Test 2.

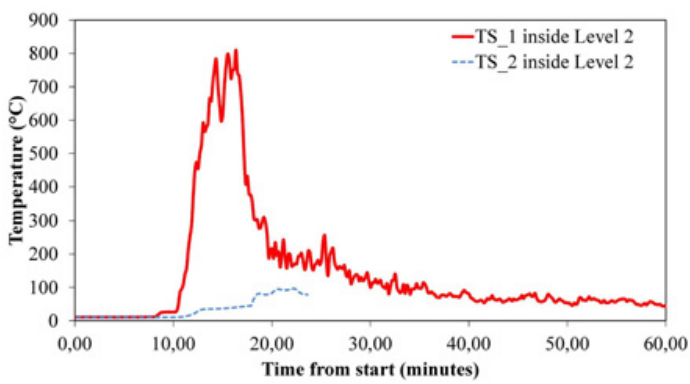

a)

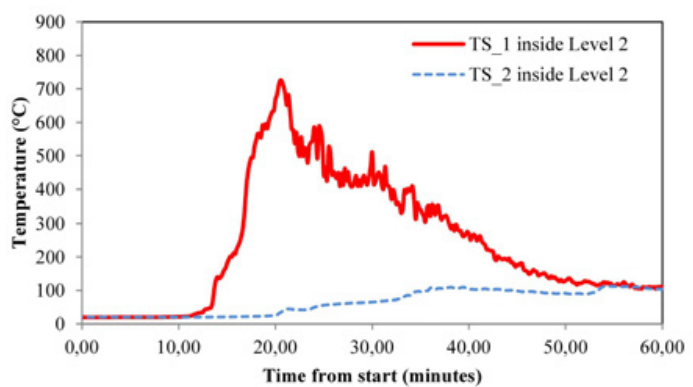

b)

Figure 6. Average temperature within thermal insulation layer at Level 2 on main facade: a) Test 1, b) Test 2.

Figure 4 and Fig. 5 are presenting temperature profiles based on average temperatures measured according to the standard [2] with external thermocouples on test specimens at Level 1 and Level 2, respectively. Figure 6 presents the average temperature measured within the thermal insulation layer at Level 2, according to the standard. Average temperatures imply an average of several thermocouples at the same level.

Development of surface temperatures on test specimens TS_1 and TS_2 in Test 1 is comparable and has practically the same increase rate and values up to $8 \mathrm{~min}$ from the test start (Fig. $4 \mathrm{a}$ and Fig. 5a). After those 8 min average surface temperatures on test specimen TS_1 are considerably higher compared to the test specimen TS_2. In case of Test 2, such a correspondence of temperatures in first 


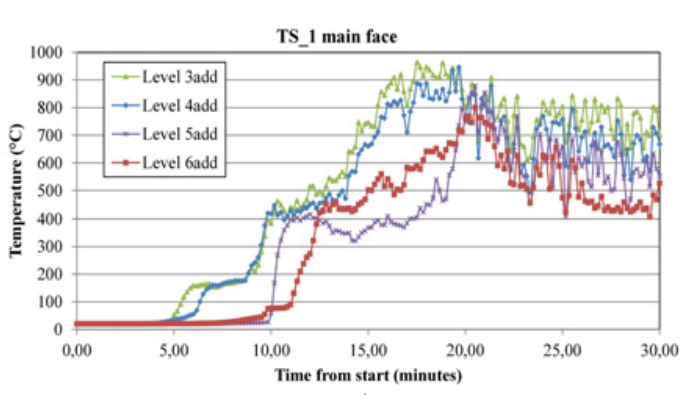

a)

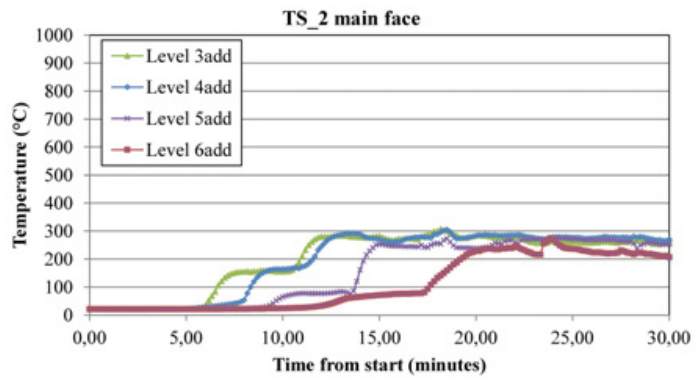

b)

Figure 7. Average temperature within thermal insulation layer at additional levels on main façade from Test 2: a) specimen TS_1, b) specimen TS_2.

few minutes from test start is not present (Fig. 4b and Fig. 5b). Although, surface temperatures on test specimen TS_1 during the Test 2 were higher compared to test specimen TS_2, thus confirming the behavior from Test 1. As it can be observed in Fig. 4 and Fig. 5, temperature profiles of test specimen TS_1 are characterized with stronger peaks, while the temperature profiles of test specimen TS_2 are characterized with a multitude of oscillations and significant peaks cannot be recognized. Temperature profiles of both test specimens, i.e. TS_1 and TS_2, follow form of the fire development curve, but the fire development curve of TS_2 has quite lower amplitude, i.e. the stages corresponding to the flashover and fully developed stage are mitigated due to presence of SW fire barrier.

When results from Test 1 and Test 2 are being compared, the differences in developed temperatures in each test can be noticed on both test specimens. Differences in surface temperatures on test specimen TS_1 reach up to $200^{\circ} \mathrm{C}$ at Level 1 (Fig. $4 \mathrm{a}$ and Fig. 4b) and up to $150^{\circ} \mathrm{C}$ at Level 2 (Fig. 5a and Fig. 5b). On test specimen TS_2, when Test 1 and Test 2 are being compared, differences in surface temperatures reach up to $150^{\circ} \mathrm{C}$ at Level 1 (Fig. $4 \mathrm{a}$ and Fig. 4b), while at Level 2 temperatures remain practically the same (Fig. 5a and Fig. 5b). It can be assumed that the differences are caused by changes in weather conditions and different burning rate of fire sources, which will be further discussed in this paper.

Analysis of average temperatures within the thermal insulation layer shows that test specimen TS_2 has considerably lower temperatures compared to test specimen TS_1. Obviously, fire barrier has limited the fire development within the insulation in test specimen TS_2 and temperatures remained below or around $100^{\circ} \mathrm{C}$ at Level 2 (both Test 1 and Test 2). The adverse effect occurred on TS_1, i.e. the thermal insulation in test specimen TS_1 caught fire and peak temperatures reached around $800^{\circ} \mathrm{C}$ in Test 1 and around $720^{\circ} \mathrm{C}$ in Test 2 at Level 2 (Fig. 6a and Fig. 6b). The first peak in test specimen TS_1 appeared around 14 min from the start in Test 1 (Fig. 6a), while in Test 2 it appeared around 20 min from the start (Fig. 6b). Possible explanation for this occurrence of peak's time shift could be change in weather conditions and different burning rate of fire source.

Analogously to the above presented tendencies of average surface temperatures, the average temperatures within the thermal insulation layer are constant and have the same value in both test specimens up to the first $8 \mathrm{~min}$ from the start in Test 1 (Fig. 6a) and up to the first $10 \mathrm{~min}$ from the start in Test 2 (Fig. 6b).

Results of additional measurement are shown in Fig. 7 and Fig. 8.

Additional measurements of temperature within thermal insulation layer were conducted only during Test 2 (Fig. 7). Additional levels marked in Fig. 3b were defined to gain an insight into the vertical fire spread within combustible insulation, with and without fire barrier. The results show that the fire barrier in specimen TS_2, caused the temperatures within thermal insulation layer up to Level 6 add $(6.0 \mathrm{~m}$ above the combustion chamber) to stay below $300^{\circ} \mathrm{C}$. However, this indicate that EPS in specimen TS_2 has melted away at least $6 \mathrm{~m}$ above the combustion chamber, as EPS starts to melt at temperatures 


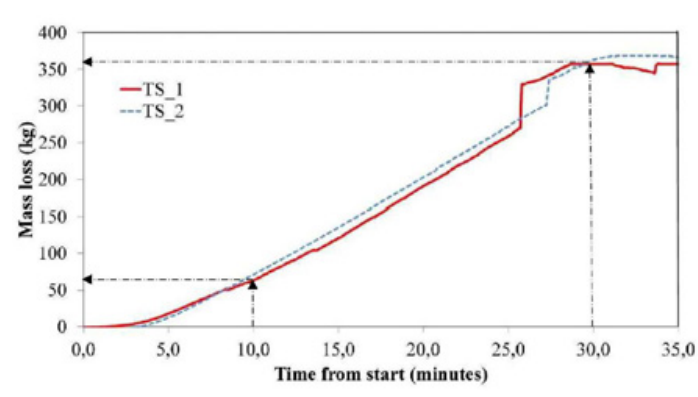

a)

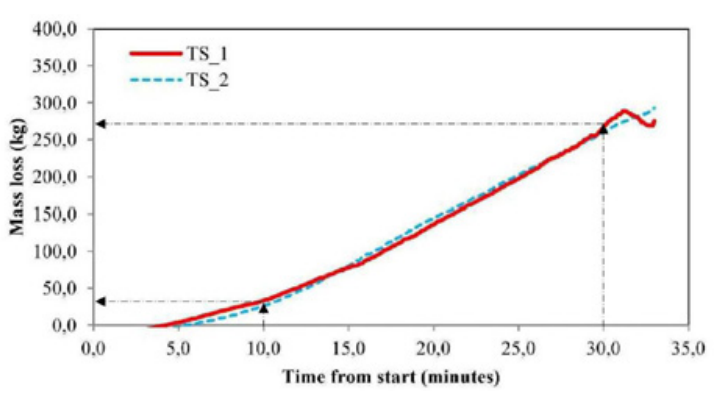

b)

Figure 8. Mass loss of wood crib: a) Test 1, b) Test 2.

above $80^{\circ} \mathrm{C}$ [6-8]. EPS melting vertically underneath uncracked render is confirmation of accelerating internal fire spread because of the occurring stack effect.

As expected the fire barrier has no influence on burning rate of the fire source, i.e. the mass loss of wood crib was practically the same for test specimens TS_1 and TS_2. That finding from Test 1 was confirmed in Test 2 (Fig. 8a and Fig. 8b). On the other hand, there is a noticeable difference in mass loss measured in Test 1 and the one measured in Test 2. In Test 2 the burning rate is decreased (Fig. 8b) compared to that in Test 1 (Fig. 8a). It should be noted that the standard [2] only defines to "nominal" volume of wood crib used as a fire source. For the same geometry of wood crib and the same type of softwood used (fir), in Test 2 the initial mass of wood crib was approximately $100 \mathrm{~kg}$ heavier for TS_1 and approximately $80 \mathrm{~kg}$ heavier for TS_2, compared with the mass of wood cribs in Test 1 . Even for the same type of softwood, its density can vary and thus affect the mass of wood crib. Also, different moisture content in the wood will affect the mass of the crib. Variation in density of softwood and its moisture content, together with changes in weather conditions, resulted with wood cribs in Test 2 that were burning more slowly, i.e. the mass loss was lower compared to the mass loss in Test 1 (Fig. 8a and Fig. 8b). Consequently, lower temperatures were developed on the surface of the test specimens and within the thermal insulation layers in Test 2 compared with temperatures developed in Test 1 (Figs. 4-6).

Since, at the moment, there is a strong effort to establish a harmonised European full scale test method for determining fire performance of building facades, it has to be highlighted that the fire source in future EN full scale test method needs to be carefully defined, whereas it can greatly affect the outcome of testing.

Figures 9-12 shows the development and fire spread on both specimens during Test 1. By visual observation during the test, it has been noted that the fastest fire spread, both vertically and horizontally, was present on the test specimen TS_1 accompanied with significantly more smoke production compared to specimen TS_2. On test specimen TS_2, fire spread was mitigated due to the fire barrier above the combustion chamber, which is also reflected in the temperature profiles (Figs. 4-7). The fire barrier however, did not prevent the fire from consuming the test specimen. The insulation above the fire barrier melted as the temperature passed the melting point and pooled on top of the fire barrier. Here it collected until the render at the lintel level broke and allowed melted material to drip out as burning droplets as well as burning on top of the fire barrier creating a delayed smoke production. The main risk with burning droplets is that they can spread the fire downwards and can also endanger firefighters in real fire cases. Smouldering was present on specimen TS_2 after the wood crib had burned out. This is assumed to be the residual melted EPS insulation slowly combusting within the fire barrier.

In both tests, after the fire sources have self-extinguished, firefighters hosed down the wood cribs and test specimens for safety reasons. For test specimen TS_1, only the glass fibre mesh and the finishing 


\section{MATEC Web of Conferences}
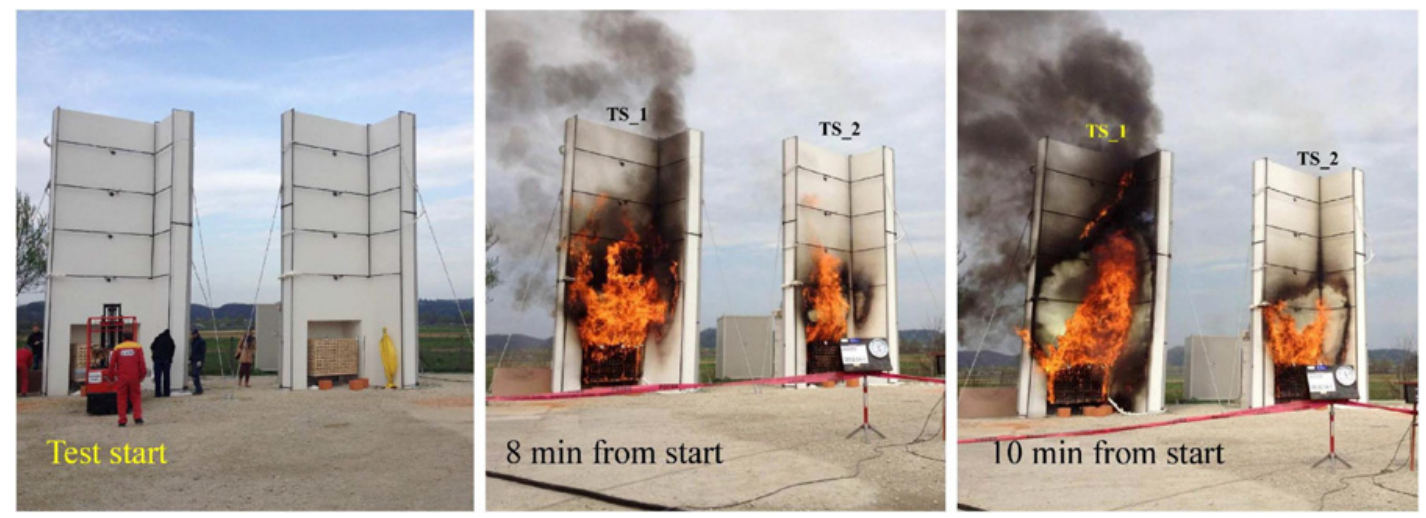

Figure 9. Visual observations of test specimens during the first $10 \mathrm{~min}$ of testing.
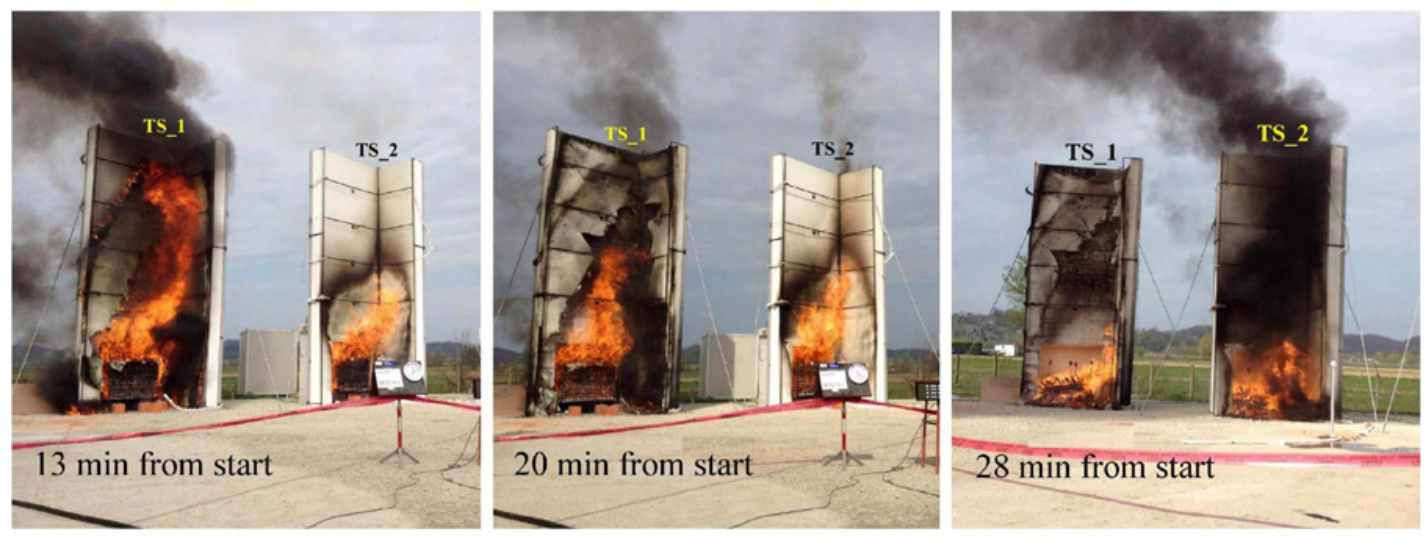

Figure 10. Visual observations of test specimens from $13 \mathrm{~min}$ to $28 \mathrm{~min}$ from the test start.

render has left, while all the EPS thermal insulation had burned out, Fig. 12. On test specimen TS_2 the EPS thermal insulation had melted only partially, Fig. 12.

All specific appearances observed during Test 1 (Figs. 9-12) have also occurred during Test 2, but at slightly later times. Nevertheless, a pattern of behaviour in this type of fire scenario can be established for tested ETICS systems as follows:

1) ETICS with EPS (TS_1): As the fire extends from the combustion chamber the organic render ignites and starts to crack. This is followed by the render opening up allowing the EPS underneath to ignite. As the EPS starts to burn the smoke emissions increase until a thick black smoke is observed, and it is followed by occurrence of pool fire and burning droplets. All the EPS in the specimen is consumed by the fire before the wood crib is burned out.

2) ETICS with EPS and fire barrier (TS_2): As with TS_1 the fire extends from the combustion chamber and ignites the organic render. The fire is "localized" on the façade above the opening. The EPS above the fire barrier starts to melt. The fire spreads up the façade in part due to melted EPS igniting and starting to burn at the level of the fire barrier. This causes a delayed smoke production as well as significant amount of burning droplets as the fire barrier can no longer contain the melted EPS. The EPS is melted only partially along the specimen height.

Time shift in specific appearances during Test 1 and Test 2 can possibly be caused by changes in weather conditions and different burning rates of fire source. Different weather conditions may cause different 


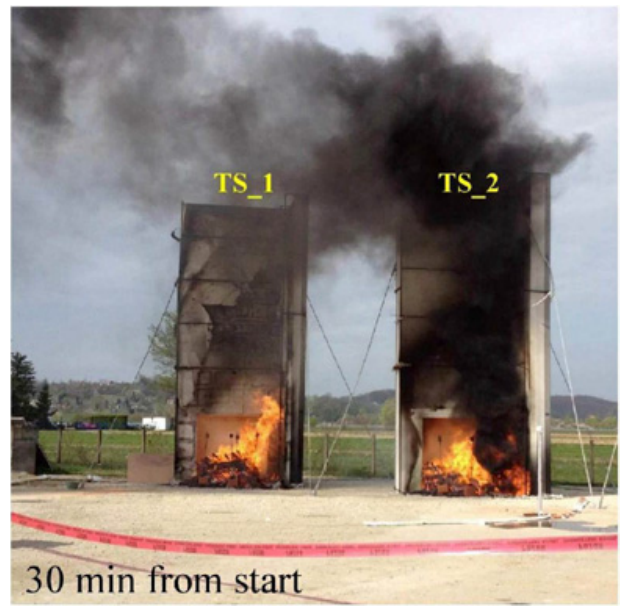

Figure 11. Visual observations of test specimens $30 \mathrm{~min}$ from the test start.
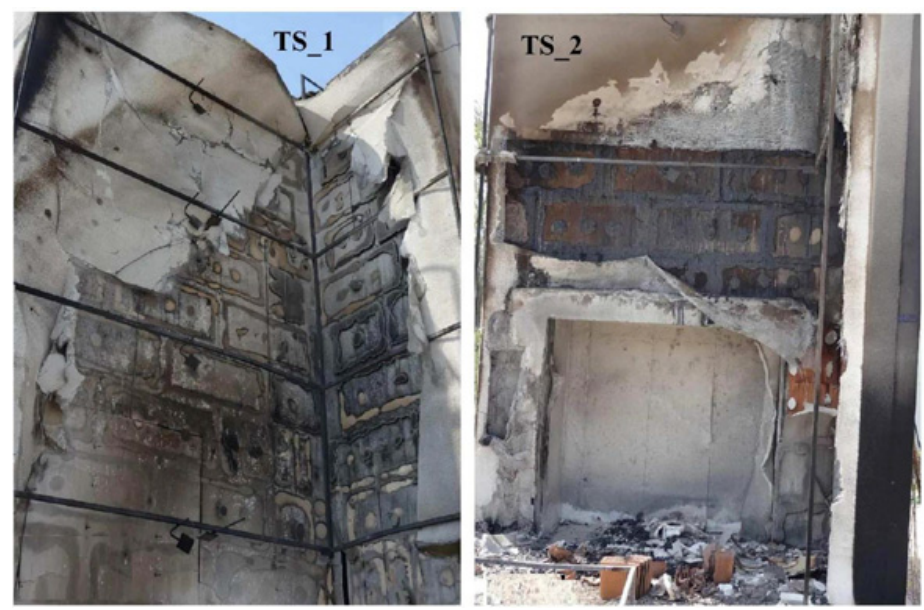

Figure 12. Test specimens TS_1 and TS_2 at the end of testing.

test outcome for the same systems tested, i.e. may cause different evaluation of fire performance. The same applies for the differences in wood cribs.

\section{DISCUSSION}

The results presented in this paper show what kind of influence a non-combustible stone wool fire barrier positioned above the window opening can have on the fire performance of an ETICS system with combustible insulation, i.e. EPS. The stone wool fire barrier has two major functions during the test:

1. It keeps the render and mesh in position longer delaying cracking of the render.

2. It absorbs melted EPS delaying the spread of fire and burning droplets.

However, the results also shows as whereas a stone wool fire barrier can slow down and decrease the fire spread in EPS ETICS it cannot fully prevent the EPS from participating in the fire. When the fire 


\section{MATEC Web of Conferences}

barrier gets saturated with melted EPS it will allow some of this to spill out through the cracks that has developed in the render resulting in a flow of burning droplets. Depending on the thickness of EPS involved it could lead to a pool fire in front of the façade as seen in this test. As more oxygen is allowed in through the cracks the melted EPS in the fire barrier will start to burn causing significant smoke production.

Consequently EPS ETICS with stone wool fire barriers cannot be considered as fire safe as systems with non-combustible insulation and hence are not suitable for all building types. When deciding on the type of ETIC system to use on a building it is important to know how the system will perform in case of fire by having it tested in an appropriate large scale test. Only then can a decision be made if the system will lead to safety in case of fire for the building and occupants in question. This emphasizes the importance of having a harmonised large scale fire test for facades in EU.

\section{CONCLUSION}

Non-combustible stone wool fire barriers if positioned above the window opening can delay the fire spread and smoke production of EPS ETICS in case of a fully developed fire impinging on the façade. Specifically it was seen that

- EPS burned out completely if no fire barrier was present, while it was melted under the render and pool fire occurred on the ground near specimen when a stone wool fire barrier was in place over the window.

- The fire barrier delayed the smoke production and burning droplets compared to the sample with no fire barrier.

- Temperature profiles show considerably higher surface temperature and temperature within thermal insulation layer on specimen when no fire barrier is used.

Therefore, in systems like the ones tested a non-combustible stone wool fire barrier can possibly be used as passive fire protection. It has to be highlighted that further research is needed to generalise this hypothesis to other systems as well.

The fact that the system with the fire barrier allowed considerable fire spread and smoke production, although later in the test, shows that the safety margin of these types of systems are limited. They should therefore not be used on buildings such as high rise buildings and buildings where occupants need additional time to escape such as hospitals, schools and nursing homes.

The testing highlights that appropriate large-scale testing of façade systems is needed in order to fully understand their behaviour in fire. It also shows that in order to sustain repeatability of the testing procedure, it is necessary that environmental factors such as wind and ambient temperature are controlled and within certain limits.

Based on the experiences form these tests the authors considers the test BS8414 as an appropriate large scale façade fire test to be used for the basis of harmonisation in EU.

\section{References}

[1] Pasker, R., "WDVS in Europa", European Association for External Thermal Insulation Composite Systems EAE, EUMEPS Master Class ETICS, Vienna, Austria, 2013.

[2] BS 8414-1:2002 "Fire performance of external cladding systems. Test methods for non loadbearing external cladding systems applied to the face of building".

[3] Šilhard Mihaljević, S., Weigand I., Jelčić M., "Potvrđivanje sukladnosti povezanih sustava za vanjsku toplinsku izolaciju (ETICS) za primjenu u zgradarstvu" Hrvatska normizacija i srodne djelatnosti - tehničko usklađivanje na putu prema Europskoj uniji, Plitvička jezera, Croatia, 2005.

[4] HRN EN 13501-1:2010 "Fire classification of construction products and building elements Part 1: Classification using data from reaction to fire tests" (EN 13501-1:2007+A1:2009). 
$2^{\text {nd }}$ International Seminar for Fire Safety of Facades, Lund (Sweden), 2016

[5] Brillux, "Technische Info 5b04, WDVS Brandschutz Grundlagen und Begriffe, brandschutzrelevante Verarbeitungsdetails", Münster, Germany, 2011.

[6] Hens, H., Performance Based Building Design 1, From Below Grade Construction to Cavity Walls, Ernst \& Sohn A Wiley Company, 2012.

[7] Banjad Pečur, I., Bjegović, D., Boström, L., Milovanović, B., Hajduković, M., "ETICS Fire Performance test", Proceedings of the Fifth International Workshop on Performance, Protection \& Strengthening of Structures under Extreme Loading, 964-971, Michigan, USA, 28-30 June, 2015.

[8] Bjegović, D., Banjad Pečur, I., Milovanović, B., Jelčić Rukavina, M., Alagušić, M., "Comparison of fire performance of ETICS systems in full scale test", Građevinar, 2016. - accepted for publishing. 